\title{
1. Introduction: the Barbarian at the gate
}

\section{CRISIS TALK}

It is now widely claimed that Europe faces a double crisis. The first is a purported 'refugee crisis'-the suggestion that the continent is overwhelmed by an unending flow of 'migrants' (a term sometimes deliberately used to avoid the humanitarian and legal obligations of states towards refugees). The second is a perceived 'terrorist crisis' - a sense that Europeans are everywhere and at any time vulnerable to murderous attack, presumptively by Islamists.

The paradox is that the statistics in both cases do not, by an order of magnitude, correspond with a 'crisis' ascription. The number of refugees annually endeavouring to enter Europe from the middle east and north Africa (MENA) region and beyond is tiny by two comparisons-with the population of the European Union (EU) and with the refugee populations much poorer neighbouring countries have absorbed. The impact on individual EU states of a reasonably shared distribution would have been well within the scope of manageability, even if one allowed that a more hospitable regime might enhance to some extent the refugee flow. In the peak year of the influx to Europe, 2015, more than 1 million refugees arrived. Yet that year, according to the United Nations high commissioner for refugees (UNHCR), 65.4 million were forcibly displaced worldwide-most of them internally-and 86 per cent of the refugees under UNHCR's mandate were hosted in low- and middleincome countries close to situations of conflict (Magennis, 2017). So the small minority of those who flee, who move beyond the region, including to Europe, are a self-selected group with resources, knowledge and/or networks (Castles et al., 2014: 57).

Of the 2.5 million Afghan refugees around the world, the vast majority are in neighbouring Iran and Pakistan. Yet European states returned far more Afghan asylum-seekers in 2016 than in previous years-in breach of the principle of non-refoulement (see below), according to Amnesty International (2017a), even as civilian deaths in the country continued to rise. In the space of just a month in August-September 2017, nearly half 
a million Rohingya refugees fled 'ethnic cleansing' by the Myanmar army in Rakhine state for impoverished, neighbouring Bangladesh. ${ }^{1}$ According to UNHCR, at the end of 2016, Turkey alone was hosting 2.9 million refugees, Lebanon 1 million-one in six of its population. ${ }^{2}$ In March 2017, the Lebanese prime minister, Saad al-Hariri, described his country as 'a big refugee camp' which was 'on the verge of a breaking point' ${ }^{3}$ By contrast, refugees comprise just 0.4 per cent of the population of the EU. ${ }^{4}$

Those numbers have, of course, been by no means evenly disbursed and individual member states have experienced asymmetric refugee shocks. The Dublin regulation, which requires those seeking asylum in the EU to do so in their country of arrival, meant that Greece, devastated by economic crisis and EU-driven austerity, suddenly became responsible for 850000 individuals fetching up in 2015, while 150000 were rescued at sea and taken to Italy.

In October that year, the EU began a two-year responsibility-sharing scheme, under which 160000 individuals were to be relocated across the union. But the Dublin system did not incentivize member states that had been receivers of significantly fewer refugees to comply (Bauböck, 2018). Indeed, although the regulation was supposed to prevent 'asylumshopping' by allowing asylum applicants to be returned to the EU member state where they had first arrived, it favours a 'race to the bottom' in asylum protection, to deter the supposed 'asylum-shoppers' (den Heijer et al., 2016: 612).

In April 2016, the European Commission said of the relocations: 'It is imperative that these measures are implemented fully and swiftly to cope with immediate challenges. ${ }^{5}$ In June 2017, the commission instigated proceedings against Hungary, Poland and the Czech Republic for their failure to comply. ${ }^{6}$ And in September 2017, the European Court of Justice dismissed a challenge to the scheme by Hungary and Slovakia. ${ }^{7}$ But Hungary remained defiant, as did Poland. ${ }^{8}$ As the two-year period was coming to a close, the commission could only report that even the modest pledges by member states, summing to 44374 , had not been met, with just 8839 relocations from Italy and 19740 from Greece. ${ }^{9}$ In December 2017, the commission itself referred the three member states to the court of justice over their non-compliance. ${ }^{10}$

This of course did not mean that the refugees disappeared: one non-governmental organization (NGO) in Thessaloniki simply providing showers for them reported that during the 2016-17 winter its waiting list had been ten days (Bird et al., 2017). Indeed, according to Amnesty International (2016a), many were meanwhile corralled in Italy by the 'hotspot' approach adopted by the European Council in June 2015, under 
which new arrivals were fingerprinted to identify them and prevent any onward movement by themselves.

Yet nor was there any correspondence between the demonstrated willingness of states to absorb refugees and a sense of being overwhelmed among their 'host' populations. On the contrary, a Pew Research Center survey in the spring of 2016 (Stokes et al., 2016) showed that the refugee influx was far less likely to be considered a 'major threat' by Swedes (24 per cent) or Germans (31 per cent) - the two states which had accepted the most refugees in Europe, in proportion to population - than by Hungarians (69 per cent) or Poles (73 per cent), where doors had been kept firmly shut.

Indeed, contrary to claims that this is an unprecedented crisis, Europe has been here before-and not in the dim and distant past. Refugees fled to Europe as Yugoslavia collapsed in 1991-96 in numbers quite similar to the flow from Syria in 2011-16 and subsequent labour-market and educational outcomes show this to have been an integration success story (Barslund et al., 2017). Irial Glynn (2017) pointedly argues:

In short, what separates the current refugee crisis is not its scale. It is that it has occurred during a perfect storm of other factors: the economic crisis, the rise of anti-immigration parties, and a media increasingly desperate for readers and arguably resorting to ever uglier coverage to keep them.

Similarly, it remains the case that Europe is a haven of peace, in two more comparisons - with the apogee of nationalist and (mainly) far-left violence in the 1970s in western Europe and with the death toll from non-state (as well as state) violence in the arc of conflict stretching from Nigeria and the Sahel via the horn of Africa, Syria and Iraq, to Pakistan and Afghanistan ${ }^{11}$ - as big-data analyses by the Washington Post have demonstrated. Even if one includes the data (often neglected in the dominant crisis discourse) on far-right violence, there has been a huge fall in the number of 'terrorist' attacks in western Europe in which at least one person died, from nearly 300 in 1972 (peak year of the violence in Northern Ireland) to fewer than ten per year since 2002, until the uptick in 2015 and 2016 (albeit fatal attacks in eastern Europe have risen from zero since the collapse of the Soviet Union). ${ }^{12}$ And the 658 deaths due to 46 such lethal attacks in Europe and the Americas from January 2015 to mid-2016 were dwarfed by the 28031 fatalities from 2063 such assaults in the middle east, Africa and Asia in the same period. ${ }^{13}$

In January 2016, two months after the Bataclan night-club and other attacks in Paris, a European Counter Terrorism Centre was established, staffed by Europol experts (Europol, 2017: 4). The horrors of such 
massive individual atrocities notwithstanding, on the widest measure the incidence of non-state violence generally has been diminishing in Europe in the past decade. Figure 1.1 is compiled from successive annual EU Terrorism Situation and Trend Reports (TE-SAT) produced by Europol since the series began. It includes failed or foiled as well as successful attacks, variously of Islamist, ethno-nationalist, far-right and far-left sources.



Source: Europol.

Figure 1.1 Failed, thwarted and successful non-state attacks in the EU by year

It might be thought that such out-of-the-blue attacks would shake social foundations, suggesting a need to buttress the state in response. Yet, counter-intuitively, they have actually tended to have a mobilizing effect on public opinion precisely contrary to that intended by the perpetrator. The attacks in Oslo and on Utøya island in July 2011 by the far-right figure Anders Breivik, killing 77, met a remarkable response from the then Norwegian prime minister, Jens Stoltenberg. Though most of the dead were youth from his social-democratic party, Stoltenberg said the answer was not to sacrifice what he described as 'our values', and he called for 'more democracy, more openness and more humanity' and a mutual love to counter Breivik's individual hatred. ${ }^{14}$ Nine months later it was the same story, as up to 40000 gathered outside Breivik's trial in Oslo-not to bay for his blood but to sing in defiance 'Children of the Rainbow', a song 
of peace celebrating the very cultural diversity everyone in the crowd knew he utterly despised. Leading the singing, Lillebjoern Nilsen said: 'It's we who win.' 15

Similar effects have been demonstrated more scientifically with regard to the Islamist attacks in Paris on the offices of the satirical weekly Charlie Hebdo in January 2015 and on the Bataclan and other sites the following November. The Charlie Hebdo attack interrupted the work of data collection for the European Social Survey in France, so some of the interviews were conducted before the event, some after. A YouGov poll which happened to be conducted in Britain shortly before the November violence was repeated in the aftermath. Analysis by three social scientists of the data-in particular, respondents' attitudes to Muslims, migrants and minorities generally_-showed a little more tolerance after the attacks than before. Disaggregated, it showed that both liberal and authoritarian respondents had been mobilized by the atrocities, in opposed directions, reflecting a general psychological truism (Stenner, 2005: 63) —-there were just more liberals (Sobolewska, 2017).

\section{MORAL PANICS}

So why this disjunction-why such disproportionality in response to these real but manageable challenges? What has turned the movement of people in Europe since the second world war from 'a non-problem to an obsession' (Castles et al., 2014: 201)? The late Zygmunt Bauman (2016: 7) opened his Strangers at Our Door with these words:

TV news, newspaper headlines, political speeches and Internet tweets, used to deliver foci and outlets for public anxieties and fears, are currently overflowing with references to the 'migration crisis'-ostensibly overwhelming Europe and portending the collapse and demise of the way of life we know, practise and cherish ... The impact of the news broadcast from that battlefield now comes close to causing a veritable 'moral panic' ...

The concept of 'moral panic' was initially developed in the 1970s by Stuart Hall et al. (2013 [1978]), to explain a massive overreaction in the United Kingdom (UK) to a perceived 'law and order crisis', connotatively linked to 'black crime'. It provides the conceptual framework to explain how an 'amplification spiral' can lead to such disproportions between objective reality and its ideological construction. Via such a spiral, taking place in and through the media and the interventions of political entrepreneurs, a social challenge is escalated into the embodiment of a purported crisis for 
the state, through which debate is closed down and only authoritarian responses become acceptable.

This has characterized the official reaction in Europe, albeit differentiated, to the influx of refugees. The expert on refugee law Violeta Moreno-Lax (2017: 2) complains that "since the beginning of the so-called "refugee/migration crisis" in 2015, EU Member States have deployed a securitarian, rather than humanitarian, response'. The UN Educational, Social and Cultural Organization (UNESCO, 2016: 1) has complained: 'The proliferation of negative perceptions of refugees and migration in general is often nurtured by the populist discourse of politicians and the negative representation of refugees by media outlets.' Addressing the UN Human Rights Council in Geneva in March 2017, the high commissioner for human rights, Zeid Ra'ad al-Hussein, said: ${ }^{16}$

Many ordinary people in Europe have welcomed and supported migrants, but political leaders increasingly demonstrate a chilling indifference to their fate. I am particularly disturbed by lurid public narratives which appear deliberately aimed at stirring up public fear and panic, by depicting these vulnerable people as criminal invading hordes.

Responses have been particularly negative in former Soviet-bloc countries. A report from NGOs in five eastern European member states on the denial of access and expulsions of refugees (Voynov et al., 2017: 3) said: 'The political discourse shaping legislative and policy measures in the participating countries is centred around issues of security and terrorism, while little or no room is left for the obligation to grant the right to asylum and to protection.'

Linking the refugee and security 'crises' in this way has ratcheted up the amplification spiral-particularly via the claim that, among their number, asylum-seekers contain the very 'terrorists' threatening Europe's security. In March 2017, following an attack near the UK Parliament in which a car ploughed into pedestrians, killing five (including the driver) and injuring around 40 people, the then Polish prime minister, Beata Szydło, said: 'I hear in Europe very often: do not connect the migration policy with terrorism, but it is impossible not to connect them.' Implicit in Szydło's claim was that this was all self-evident to ordinary Poles but the authorities 'in Europe' (presented as an external entity) were suppressing the truth, and freedom of expression, in pursuit of their project to force Poland to accept refugees. And indeed she said, as if vindicated: 'The commissioner is coming to Warsaw and trying to tell us: you have to do what the EU decided, you have to take these migrants ... Two days later another terrorist attack in London occurs. ${ }^{17}$ 
Yet the European Commission has helped to assemble the neuralgic connotative chain connecting refugees and security itself. Following the 2014 victory in the first Spitzenkandidaten European Parliament elections of Jean-Claude Juncker of the centre-right, and in line with 'political guidelines' he subsequently set out, in April and May 2015 a European Agenda for Security ${ }^{18}$ and a European Agenda for Migration ${ }^{19}$ were respectively published by Juncker's commission. By September 2016 however, when the commission issued a communication entitled 'Enhancing security in a world of mobility: improved information exchange in the fight against terrorism and stronger external borders'20_promulgated days before a new 'commissioner for the Security Union' was appointed - these two strands had become interwoven. Before referencing the two prior agendas in the third sentence, the document claimed: 'The pressures of the migration and refugee crisis, alongside a wave of terrorist attacks, have demanded a new approach.' And the linkage was sustained by adopting such language as 'irregular arrivals'-though article 31 of the 1951 Convention Relating to the Status of Refugees (the Geneva convention) requires that states-party do not impose penalties on refugees entering their country unlawfully-and 'foreign terrorist fighters'.

As for the media, an analysis of the discourse of UK news in 2015 and the first part of 2016 (Goodman et al., 2017) found, first, that the refugee influx was described from the outset as a 'migrant crisis', thereby dissolving the swath of humanity involved into a wider category neither meriting humanitarian sympathy nor due international legal obligations (and with the implication that asylum claims submitted on arrival might well be 'bogus'). After the drowning of Alan Kurdi-the three-year-old Syrian, washed up on a Turkish beach in September 2015-the language however changed, and a 'refugee crisis' was discussed (albeit still with the implication that the 'crisis' was for Europe, rather than a humanitarian crisis for those in flight). This was, though, to be short-lived: after the attacks in Paris the following November, the language of 'migrants' returned-now charged by the implication that they included 'terrorists' among their ranks. Far from those struggling to arrive being deserving of support, as under the refugee convention, they thus became redefined as an immoral group which Europe should keep at bay.

In fact, an analysis of the 36 jihadist attacks in Europe and 15 in the United States (US) in the three years after the declaration of its 'caliphate' by 'Islamic State' in June 2014 found that 73 per cent of the perpetrators were citizens of the countries where the attack took place and only 5 per cent were refugees (Vidino et al., 2017). In four focus groups across Europe in November and December 2016, in which 
participants were invited to offer their thoughts on migration and border security, not one volunteered the suggestion that the 'migrants' might be 'terrorists' as well (Vaughan-Williams and Löfflmann, 2017). In the US, such thinking of course underpinned the 'Muslim ban' which Donald Trump sought to introduce soon after his inauguration as president in January 2017. Yet in the previous 40 years there had not been a single 'terrorist' killing in the US by individuals of any of the seven nationalities initially targeted. ${ }^{21}$

A further research report on media coverage of the 'refugee crisis' (placed between quotation marks), published by the Council of Europe in 2017, came to similar conclusions. The year-long study was a content analysis of the 'quality' press in eight European countries. Georgiou and Zaborowski (2017: 4) point out that throughout the events of 2015 and 2016 'the media played a central role in ... framing these events as a "crisis". They analysed the coverage along an axis with militarization (control of borders and Europe's security) at one end and humanitarianism (compassion towards new arrivals) at the other. Their exhaustive study of 1200 articles found that two-thirds referred to negative consequences of refugee arrivals - even early on when any such attributions were speculative. Fifty-nine per cent mentioned no positive consequences and any such positive framing tended to be in terms of moral imperatives, rather than real or tangible developments flowing from the influx (a point elaborated in Chapter 10).

In the same vein as Goodman et al. (2017), Georgiou and Zaborowski (2017: 9) found that what were initially presented as economic and cultural consequences of the arrivals escalated to the level of 'geopolitical dangers' after the Paris attacks, while initial sympathy for the refugees' plight was replaced by a 'defensive, militaristic frame'. Refugee voicesparticularly those of women-were rarely quoted, as compared with government representatives, and indeed only 16 per cent of articles even named any refugees, while just 7 per cent said what they did. Georgiou and Zaborowski (2017: 10) conclude:

Refugees thus emerge from these narratives as an anonymous, unskilled group. They are 'the other' to the presumed reader of the press and this limited characterisation shapes the discourse surrounding the refugee crisis for both European audiences and stakeholders. In the mediated narrative, without individual characteristics, refugees are implied to be of little use for European countries (as they seem to have no profession), inspiring little empathy (because they are dehumanised and de-individualised) and raising suspicion (because no gender distinction aids the narrative of refugees being 'mostly young men chancing their luck'). 
Much earlier, Bauman (2004a: 57) had already identified how by being inserted into these chains of signifiers with such negative connotations, refugees were being dehumanized:

Overgeneral, unwarranted or even fanciful as the association of terrorists with asylum-seekers and 'economic migrants' might have been, it did its job: the figure of the 'asylum-seeker', once promoting human compassion and spurring an urge to help, has been sullied and defiled, while the very idea of 'asylum', once a matter of civil and civilized pride, has been reclassified as a dreadful concoction of shameful naivety and criminal irresponsibility.

Shortly after, Schierup et al. (2006: 263) caustically criticized the then initial years of the Common European Asylum System (CEAS) as comprising 'policies that export securitized migration measures' and which thus perpetuate the transfer of responsibility for refugees globally 'from richer to poorer countries'. And, latterly, Bauman (2016: 26) added that the substitution of security for solidarity allowed many to 'feelknowingly or not-glad to be relieved of responsibility for the fate of the wretched, as well as of the pressures of a moral duty that otherwise would inevitably follow to torment the bystanders'.

This amplification spiral is driven by another paradox, which I call the 'paradox of security' (Wilson, 2015)—-that taken-for-granted 'security' responses to challenges of insecurity tend not only not to work but, if anything, to enhance the very fear they are supposed to assuage. This is evidenced in the numerical failure of the efforts to stem, as against displace, refugee flows (though they have continued to foster refugee deaths) and the inevitability of the maintenance of initially temporary 'states of emergency', as in France, because they do not succeed in ending violence (though they certainly foster alienation). And yet a self-justifying prophecy is set in train: the more a sustained or even escalating threat can be identified, the more 'security' can, and purportedly should, be ratcheted up.

In 2010, a Group of Eminent Persons, led by the former German foreign minister Joschka Fischer, was commissioned by the secretary general of the Council of Europe to address the resurgence of intolerance. It presciently warned (Group of Eminent Persons, 2011: 18) that '[f]rom northern Europe to the Mediterranean we are witnessing a wave of radical populism'. Too many refugees were being labelled 'bogus' asylum-seekers (ibid.: 21) and state 'overreaction' to the influx and to non-state violence represented a 'serious risk' to the health of European democracies (ibid.: 24). The group made an insightful comment in a footnote about the dilemma in which Muslims in Europe were thereby being placed (ibid.: 44): "The current discourse about "Islam" effectively 
forces them to choose between distancing themselves from their religion or assuming it as a primary identity. It is not a choice that anyone should be obliged to make.'

\section{BUILDING WALLS}

The principal manifestation of the anti-refugee measures has been walls, fences and border guards-however fundamentally at odds with a key principle of the refugee convention. Frelick et al. (2016: 198) describe it thus:

Perhaps the most important obligation, that of non-refoulement, prohibits states from returning a refugee to territories where her or his life or freedom would be threatened on account of race, religion, nationality, membership in a particular social group, or political opinion. The principle of non-refoulement also prohibits states from returning anyone to a state in which they would be exposed to the danger of torture or cruel, inhuman or degrading treatment or punishment ... These obligations require that states provide migrants access to screening and examination of any refugee or asylum claims, including in situations of mixed migratory flows (where not all migrants may ultimately be determined to merit or require international protection).

The UN International Covenant on Civil and Political Rights and its counterpart on social, economic and cultural rights both outlaw discrimination by nationality and the UN treaty bodies have made clear this applies to migrants and refugees (UNESCO, 2016: 6).

Initially, the walls were constructed at the borders between EU and non-EU states. Indeed, not content with building a $155 \mathrm{~km}$ fence in 2015 along its border with Serbia, which saw nearly 20000 individuals denied access in the second half of 2016 alone (Voynov et al., 2017: 12), in 2017, Hungary added a second layer of fencing - complete with alarms and thermal-imaging cameras. ${ }^{22}$ In March 2017, the European Court of Human Rights ruled in favour of two Bangladeshi asylum-seekers who had been detained at the border. The court said they had been deprived of their liberty and had not been granted an individualized assessment of their asylum claims before being inappropriately expelled. ${ }^{23}$ In September 2017, in Budapest, the UN high commissioner for refugees, Filippo Grandi, felt obliged to remind his hosts: 'Seeking asylum is not a crime.' $^{24}$

Some 6000 were left stranded in Serbia as a result of these barriers. Save the Children said in January 2017 that 1600 had been pushed back illegally by Hungary and Croatia in just the previous two months. Two 
thousand, including unaccompanied children, were forced to sleep rough in an abandoned warehouse in Belgrade in winter temperatures touching -15 degrees Celsius, according to a Save the Children representative, Gemma Parkin, who said it was 'the worst humanitarian crisis you could envisage in Europe' ${ }^{25}$ But Serbia's focus was on protecting its borders. In July 2016 the prime minister, Aleksandar Vučić, said: 'Serbia cannot be a parking lot for Afghans and Pakistanis whom no one else in Europe wishes to accept. ${ }^{26}$

What has perhaps been most poignant is how the eastern Mediterranean route became blocked by a succession of barriers that were established in the successor states of former Yugoslavia-its official 'Brotherhood and Unity' a distant memory. In March 2016, Slovenia, Croatia, Serbia and Macedonia closed their borders and left thousands of refugees in limbo. In a joint investigation with two ex-Yugoslav NGOs, Oxfam (2017) documented violent pushbacks and collective expulsions, in contravention of article 4 of protocol 4 of the European Convention on Human Rights. At the EU's eastern border, Polish border guards have routinely forced back asylum-seekers from the Caucasus and central Asia seeking to enter via Belarus, having concluded they are 'economic migrants' after perfunctory screening, according to Human Rights Watch. ${ }^{27}$ There were more than 72000 denials of entry by border guards in the first nine months of 2016 (Voynov et al., 2017: 18).

Inevitably, over time a 'Europe without borders' has been turned more and more into a Europe of walls, displacing those desperate to flee towards the perilous crossing of the central Mediterranean and enclosing asylum-seekers in camps in indefinite limbo. As den Heijer et al. (2016: 616-17) point out, it is simply not realistic to seal Europe's $42673 \mathrm{~km}$ of sea and $7721 \mathrm{~km}$ of land borders, and any such project to deter refugees would either fail through encouraging reliance on human traffickers and causing greater deaths at sea or succeed at the expense of breaching the principle of non-refoulement.

As will be apparent in Chapter 5, in an exact parallel with the manner in which national 'solutions' have been imagined for the economic crisis in Europe through the imposition of austerity-when the socialization of debt could have proved much more manageable and allowed Europe to recover-here too movements of people representing a tiny fraction of Europe's overall population have been turned into a crisis when genuinely collective solutions would have been relatively undemanding. The European commissioner for human rights, Nils Muižnieks, recorded despairingly in the foreword to his 2016 report that, by the end of the year, 'European co-operation on migration had reached a low pointbuilding fences had become a common practice'. ${ }^{28}$ 
Moreover, as with all moral panics, there is no necessary correspondence between official and media accounts of public opinion, presented as febrile and neuralgic - 'something must be done'-and what that opinion actually may be. In the focus group research referred to above (Vaughan-Williams and Löfflmann, 2017), participants were divided into pro- and anti-migration subgroups based on an initial attitude survey. The focus groups were run in Nottingham in England, Munich in Germany, Thessaloniki in Greece and Miskolc in Hungary but only the anti-migrant subgroup in Hungary backed their government's fence-building. The others, while airing concerns about purported job competition and the supposed 'otherness' of Muslim migrants, wanted more reliable information about irregular migration than they felt the media provided. Many, including in the anti-migrant camp, recognized their state's obligations to refugees, partly in light of Europe's colonial legacies and current interventions, and were supportive of German Willkommenskultur. More generally, rather than demanding more border security to keep incomers at bay, these participants were concerned that a process of integration take place vis-à-vis those who arrived (see Chapter 10).

It is true that most Europeans find the movement of people from outside the EU more challenging than from within. Before the 'refugee crisis', in autumn 2014, 52 per cent of Eurobarometer respondents said migration within the EU evoked a 'positive feeling', compared with 41 per cent negative responses, whereas immigration from outside the EU evoked a positive reaction among only 35 per cent, with 57 per cent feeling negative about it. ${ }^{29}$ But the significant point is the trend. Contrary to the claims by xenophobic political entrepreneurs of rising public anger-reaching 'breaking point', as the infamous UK Independence Party billboard, featuring hordes of non-white migrants, put it during the 'Brexit' referendum ${ }^{30}$-Europe's sangfroid has been remarkably unaffected: in spring 2017, 38 per cent said they felt 'positive' about non-EU immigration, with 54 per cent negative about it. ${ }^{31}$

On attitudes towards refugees specifically, after the peak year of movement in 2015, the 2016 edition of the European Social Survey asked respondents whether they agreed with the statement 'Government should be generous judging applications for refugee status'. This is quite an exacting test: it implies governments should give asylum-seekers the benefit of the doubt, rather than simply being fair and reasonable in their adjudications. Nevertheless, across the survey countries, 32.8 per cent agreed or agreed strongly with this affirmation, while 40.9 per cent disagreed or disagreed strongly. On this evidence, Germany's Willkommenskultur was under pressure: there only 27.2 per cent agreed, while 
48.9 per cent disagreed. Yet in Sweden, having accepted more refugees in proportion to its population than any other European country, fully 48.2 per cent remained 'generous', with only 17 per cent dissenting. And nor could the pressure of actual refugees explain the xenophobia in the Czech Republic, where, in line with official rhetoric, just 11.9 per cent supported generosity towards refugees, with fully 69.5 per cent averse to it. ${ }^{32}$

While populist figures generally represent themselves as passively rehearsing the vox populi, as will be evident from the discussion of scapegoating in Chapter 5-including vis-à-vis the Czech Republicthey rather act as popular ventriloquists, redefining what can and cannot be said in public by their supporters (Wodak, 2015). So leadership matters: in their study more broadly of attitudes to cultural diversity in the Netherlands, Sniderman and Hagendoorn (2007) showed that respondents took cues from parties they supported and modified their personal opinions accordingly. A few months after his election as president of France in May 2017, Emmanuel Macron, in a keynote speech on Europe at the Sorbonne, said: 'Making a place in Europe for refugees who have risked their life is our duty.' Albeit linked with calls for rapid deportation of unsuccessful asylum-seekers and a European frontier police, it was a rare acknowledgement of the responsibilities of statesmanship. ${ }^{33}$

For the most part, as Frelick et al. (2016) highlight, EU policy has been one of 'externalization'-sometimes conveniently dressed up as seeking to prevent refugees engaging in dangerous journeys (although safe routes to Europe would clearly be their preference). Amnesty International (2017d: 5) has complained: 'Rather than creating a bold, orderly system providing safe avenues for people to seek protection in Europe, European leaders have increasingly focused on blocking borders and negotiating with human rights violating governments to stop them coming.'

For Amnesty this was encapsulated in the deal between the EU and Turkey in March 2016, building on a history of prior readmission agreements with third countries, most 'with deplorable human rights records' (Schierup et al., 2006: 76). Although Turkey refused asylum to non-Europeans (Frelick et al., 2016: 208), it was offered various incentives, including financial, to accept the return from Greece of asylumseekers deemed not to have admissible claims and 'irregular migrants' who had used that eastern Mediterranean route to arrive in Europe, with, in theory, an equivalent countermovement of Syrian refugees from Turkey into the EU. In fact, as Turkey turned into an even more authoritarian regime after the failed coup four months later-up to and 
including claims of torture ${ }^{34}$ - there was little movement of Syrian refugees out of Turkey, while on the other side of the Aegean, few asylum-seekers were transferred from the Greek islands to the mainland (Amnesty International, 2017d: 6).

Thousands thus became corralled in camps on the islands, their mental health correspondingly seriously deteriorating. ${ }^{35}$ Médecins sans frontières (MSF) reported one year on that its psychologists had detected a 2.5 times increase in the incidence of anxiety and depression and a threefold rise in post-traumatic stress disorder on Lesbos (MSF, 2017: 13). Save the Children found 'most shocking and appalling' the extent of self-harm and attempted suicide among children in the camps. ${ }^{36}$ In April 2017, the Pope compared refugee holding centres in Greece and Italy with 'concentration camps' and the EU Court of Auditors warned of the plight, especially of the 23000 unaccompanied minors, assembled in facilities with inadequate security, food and water, blankets and medical care. ${ }^{37}$ In September, UNHCR warned: 'Many of the people have been staying on the islands for months and the conditions have affected their physical and mental health. The threat of violence, self-harm and sexual assault is extremely worrying and more security is needed. ${ }^{38}$

As winter 2017 approached, Der Spiegel described the insanitary conditions on the overcrowded Lesbos camp as 'ground zero of European ignominy'. ${ }^{39}$ MSF said the situation was 'beyond desperate' 40 and Oxfam said that as of 1 December there were 12744 refugees in facilities on the islands with a total capacity for 5576; the Greek government pledged to remove 5000 to the mainland before the winter. ${ }^{41}$ But in one sense the scheme was 'working': the number of refugees arriving in Europe via the eastern-Mediterranean route was 92 per cent lower in the first six months of 2017 than in the corresponding period a year earlier (UNHCR, 2017: 1).

Even keeping ports open to refugees has, apparently, been too much to ask. Italy, the destination for most of the desperate who have made the Mediterranean crossing - more than 360000 did so just in 2016-failed to persuade EU interior ministers in July 2017 to that effect. The latter did, however, agree to do more to deport failed asylum-seekers and support the Libyan coastguard. ${ }^{42}$ Amnesty International (2017b) and Human Rights Watch ${ }^{43}$ have, however, contended that the EU should not thus outsource its responsibilities when the Libyan coastguard is lacking in capacity to conduct search-and-rescue operations. A UN expert panel had found 'grave human rights violations' by coastguard officers, including the sinking of refugee boats. ${ }^{44}$ A Libyan coastguard officer told Al Jazeera: 'Europe does not want to help us. Europe wants to stop seeing the dead. European leaders only want to shift the problem, not to solve it. ${ }^{35}$ 
In Libya itself, where competing administrations jostle for power, ${ }^{46}$ there is a network of detention centres for refugees and migrants where there have been serious rights abuses, including forced labour, torture and sexual violence-two UN bodies reported 'a human rights crisis' there in December 2016. ${ }^{47}$ After a visit in May 2017 the UN high commissioner for refugees, Grandi, said he was 'shocked at the harsh conditions' and called for alternatives to detention. ${ }^{48}$ In August 2017, Oxfam published evidence from 158 refugees who had made it from Libya to Sicily, exposing huge levels of trauma: all but one of the women interviewed had been subject to sexual violence and 74 per cent overall had witnessed the torture or murder of a travelling companion. Oxfam called on the EU and its member states to offer safe routes to asylum. ${ }^{49}$ In September, al-Hussein aligned himself with MSF in criticizing the 'cynical complicity' of European leaders: 'Returning people to detention centres where they are held arbitrarily, and face torture, rape and other serious human rights violations is a clear breach of the international law prohibition of "non-refoulement". ${ }^{50}$ In December, Amnesty International (2017e: 8) published a damning report pointing out that Libya had not signed the refugee convention and that, in the absence of a functioning judicial system, officials and smugglers were engaging with impunity in egregious human-rights violations and corrupt exploitation of the plight of refugees-all with the collusion of European capitals:

Despite being fully aware of the serious violations to which refugees and migrants are subjected in Libya, European governments have decided to implement migration-control policies that, by reinforcing the capacity and commitment of Libyan authorities to stop sea crossings, are trapping thousands of women, men, and children in a country where they are systematically exposed to abuse and where they have little chance to seek and obtain protection. In the absence of any adequate mechanisms to monitor respect for and protection of the human rights of refugees and migrants in Libya, or any meaningful steps to improve the protection of their rights, these policies have directly contributed to worsening the situation of those now trapped in the country.

But the Italian government could draw satisfaction from a significant fall-off of arrivals from north Africa in the latter part of 2017. ${ }^{51}$

\section{PUSHED, NOT PULLED}

Behind this outsourcing of Europe's internal challenge to countries which are politically unstable and in the midst of their own humanitarian crises 
(Rogan and Tubakovic, 2017) has been a stubborn reluctance to face the reality that refugees have been pushed to flee the ever-more-unstable MENA region, and the wider arc of conflict referred to above, with the associated obligations that places on EU member states. Indeed, as early as 2003, just four years after the Tampere European Council had initiated construction of the CEAS, a European Commission communication asserted that 'the crisis in the asylum system' was 'more and more striking in certain Member States' and '[a]buse of asylum procedures' was 'on the rise'. ${ }^{2}$ A Foreign Policy investigation concluded in 2017:

The result is the present set of compromises that comprise European policy toward the recent surge in African migration: a rhetorical commitment to accepting anyone with a legitimate claim to refugee status paired with a host of measures-including development and security assistance to African dictatorships and fragile states-designed to prevent as many people as possible from making that claim by persuading, or compelling, them to not leave Africa in the first place. ${ }^{53}$

Instead, the people-smugglers who have been profiting from desperation - in the absence of safe, legal routes to Europe-have been self-servingly represented as among a number of 'pull' factors supposedly manufacturing the flow (Frelick et al., 2016: 192). Yet Bauman (2016: 8) pointed out that the reason for the surge in 'migrants' in recent years was the growing number of collapsing states engendering refugees - to a large extent 'the collateral damage done by the fatally misjudged, ill-starred and calamitous military expeditions to Afghanistan and Iraq'.

European powers have been to varying degrees involved or complicit in 'western' interventions in Somalia, Afghanistan, Iraq and Libya in recent times - states which have become key sources of refugee flowswhose 'strategic or political aims have foundered almost without exception' (Hippler, 2017: 6). Indeed, the 'leaving policy to soldiers' approach to conflict management has simply tended to 'reinforce and amplify the instability' and is very different from dealing with 'the causes of flight' (ibid.: 8).

UNHCR data on the 850000 arrivals by sea in Greece in 2015 showed over 90 per cent came from the top ten countries from which refugees were escaping. Interviews with 500 individuals arriving by the centraland eastern-Mediterranean routes in the last quarter of 2015 found that 72 per cent had been employed before undertaking their journey, belying the 'economic migrants' stereotype. Those on the move had little knowledge of the migration policies of individual country destinations. Agents were almost universally availed of for irregular journeys because 
of the absence of safe, legal routes (Crawley et al., 2016). UNHCR (2015: 2-3) complained: 'Most people arriving by sea are fleeing from war, conflict or persecution at home, as well as deteriorating conditions in many refugee-hosting countries. EU States have a clear responsibility to offer them protection, and an obligation along with others to rescue people in danger at sea.'

A research project (d'Angelo et al., 2017) mapping refugee reception in Europe surveyed 750 individuals who fetched up in Malta, Sicily and Greece in 2016. Asked why they had left their country of origin, they overwhelmingly blamed 'war', 'persecution or targeted violence' or 'concerns regarding family security'. Only a small minority volunteered 'work-related' or 'economic reasons'. As to why they had chosen the country of arrival, the vast majority said they had had no choice or alternative (Malta, Sicily) or they had seen it as a transit country or the most convenient (Greece). The researchers concluded (ibid.: 15): 'This finding affirms other research which claims that most of those who reached Europe during the research period were drawn by "push" rather than "pull" factors and represent a predominantly asylum-seeking population.'

In 2016, the International Organization for Migration's Missing Migrants project recorded 5098 deaths in the Mediterranean-nearly twice as many as in the rest of the world (2665) ${ }^{54}$ Yet the Italian Mare Nostrum search-and-rescue operation was deemed by some to be acting as a 'pull' factor and at the end of October 2014 was replaced by the geographically narrower and more security-focused Operation Triton, run by the EU border agency Frontex. ${ }^{55}$ Two years later, it in turn was replaced by the European Border and Coast Guard: ${ }^{56}$ with more than twice as many staff and more than three times as big a budget as its predecessor, this was 'Fortress Europe' encapsulated.

Even the NGOs involved in compensating for the associated loss of search-and-rescue capacity have been the subject of projection-as supposed 'pull' factors too. One Italian far-right politician described them as a 'taxi service' for illegal migrants (McMahon, 2017b), and an Italian prosecutor opened an investigation in March 2017 into potential connections between the humanitarian NGOs and smuggling operations. ${ }^{57}$ Research mapping the population movement across the Mediterranean over time, however, showed that the NGO activity had had no impact on its scale but had reduced the fatalities (Forensic Oceanography, 2017). Amnesty International (2017b: 16) concurred, arguing that 'but for their efforts the death toll would certainly be far higher'. Yet the Italian authorities persisted, seeking to impose on the NGOs a code of conduct. Some refused to sign it, including MSF, which claimed the code 
conflicted with humanitarian principles. $^{58}$ In August 2017, MSF suspended under protest the operation of the largest rescue ship operating off the Libyan coast-which had saved 1500 refugees in May aloneafter the Libyan navy said it was setting up its own search-and-rescue zone which the NGO vessels could not enter without authorization..$^{59}$ The organization warned of more deaths at $\mathrm{sea}^{60}$ and Save the Children and Sea Eye followed its lead. ${ }^{61}$

In a sharply critical comment, the UN special rapporteur on extrajudicial, summary or arbitrary executions, Agnes Callamard, said: ${ }^{62}$

As long as migrants and refugees who transit through or are returned to Libya are at risk of gross human rights violations, including arbitrary killings, Italy must provide search and rescue on the Mediterranean, uphold the prohibition on refoulement and ensure that NGOs can contribute fully to this end.

UNHCR $(2017: 9,11)$ concurred, affirming that NGOs continued to "play a critical role in saving lives', accounting for four in ten rescues, according to the Italian coastguard, in the months of March to May 2017. It demanded EU states provide safe legal pathways, strengthen asylum procedures, protect unaccompanied children, support family reunification and accelerate emergency relocation.

Even unaccompanied minors have been considered not as an object of compassion but as yet another 'pull' factor. Across Europe, states have been leaning towards offering subsidiary protection, rather than full refugee status, to restrict the right to family reunification. ${ }^{63}$ Denmark and the UK deny refugee children the opportunity to apply for adult family members to join them at all. The UK Home Office said that to do otherwise would 'create perverse incentives for them to be encouraged, or even forced, to leave their family, risk hazardous journeys and seek to enter the UK illegally in order to sponsor relatives' ${ }^{64}$

This is not how things look from the standpoint of practitioners on the ground. 'European leaders continue to believe that by building fences and punishing those who still try to cross them, they will deter others from fleeing for their lives,' said Aurelie Ponthieu, MSF humanitarian adviser on displacement. 'Every day we treat the wounds, both physical and psychological, inflicted by these deterrence policies. Such measures have proven to be not only inhumane and unacceptable, but also completely ineffective. ${ }^{65}$ According to UNICEF (United Nations Children's Fund, 2017: 6), 92 per cent of children making the risky central Mediterranean crossing and arriving in Italy in 2016 and the first two months of 2017 did so unaccompanied: 'But barriers to legal migration do not stop people from moving, they only push them underground. Whenever 
families and children desperate to move encounter barriers, smuggling in human beings thrives.'

As for the academic experts, den Heijer et al. (2016: 641) conclude their assessment thus:

The prohibition approach to refugee movement is both unrealistic (refugees are bound to seek safety, whether we like it or not), and it is illegitimate morally (Art. 14 of the Universal Declaration of Human Rights grants everyone the right to seek asylum) as well as legally (the principle of non-refoulement) ... It has to be emphasized that the present European crisis is a crisis of refugee policy, not a refugee crisis. The numbers in themselves are not the problem; the way in which the European Union deals with them is.

Similarly, Simon McMahon (2017a) argues: 'After a decade of repeatedly declaring migrant crises and emergencies at their borders, it is time the EU took a broader, longer-term approach ... Intensifying border controls without addressing the reasons why people move or providing alternatives is likely to reinforce the dangers that they face.' Indeed, as Castles et al. (2014: 5) point out, irregular movement-in a context where push rather than pull factors predominate-is often the paradoxical result of tighter controls.

The editors of the first systematic academic treatment of this episode (Niemann and Zaun, 2018: 12-13) contend: 'The so-called European "refugee crisis" should ... more accurately be termed a crisis of the CEAS.' Harmonization of asylum policies 'has barely led to the implementation of minimum protection standards in the EU, let alone common standards' (ibid.: 12). The EU, they write, has been more effective in limiting migration flows than ensuring a fair and long-term distribution of refugees (ibid.: 13): 'In addition, security-oriented measures have dominated over measures to ensure the protection of human and civil rights of asylum-seekers.'

It has looked very different, too, from the perspective of universal norms. In 2016, the European commissioner for human rights published a paper on migrant integration which concluded (Huddleston, 2016: 33-4):

Integration support should not be misinterpreted as 'pull factors'. These restrictions go against the letter and the spirit of European law and standards ... If Europe secures orderly arrivals at the borders, legal pathways to Europe and a rapid recognition of beneficiaries of international protection, then national governments and stakeholders will be more likely to focus their energy on integration ... In the absence of a common European response, crisis-thinking is short-term. Europe will need to look again to the long term and see integration as a long-term investment. 
In February 2015, to coincide with an EU summit in Brussels, the UN special rapporteur on the human rights of migrants, François Crépeau, issued a forthright statement: ${ }^{66}$

It is appalling to see how the discussion concerning migrants has been lowered to the smallest common dominator, feeding off fear and xenophobia and making migrants fair game for all types of verbal or physical abuse. Migrant-bashing has dangerously become the norm and the standard is so low now that to have a meaningful and serene discussion about rights, diversity and integration is often impossible ... I continue to urge European political leaders to show moral and political leadership in fighting much more vigorously racism, xenophobia and hate crime, by consolidating our common human rights culture and strengthening its institutions at all levels, and in celebrating the diversity of cultures and religions as an enrichment for everyone, citizens and foreigners alike.

UNESCO (2016: 20) also warned: 'The increased control of borders, interdiction at sea, and externalization of EU border and migration control can be seen to challenge fundamental values associated with a Europe of freedom, justice and human rights. These measures ... risk contributing to a de-solidarization of Europeans with not only refugees, but more broadly with all migrants and foreigners in Europe.' Amnesty International (2016b: 26) was equally blunt:

In the face of the worst displacement crises in generations, the European Union (EU), the richest political bloc in the world, has actively sought to prevent asylum-seekers and refugees from accessing its territory. In what have been dubbed 'Fortress Europe' policies, the EU has erected fences at land borders, deployed ever-larger numbers of border guards, and struck deals with neighbouring countries to keep people out.

Finally, on behalf of the global citizenry, in September 2016, the UN General Assembly agreed a comprehensive New York Declaration for Refugees and Migrants, reaffirming universal norms and the associated international legal acquis. The declaration began by noting that although today's mobility was unprecedented, humanity had been on the move since earliest times. And it said: 'We reaffirm and will fully protect the human rights of all refugees and migrants, regardless of status; all are rights holders.' Indeed the declaration was explicit in this regard: 'We declare our profound solidarity with, and support for, the millions of people in different parts of the world who, for reasons beyond their control, are forced to uproot themselves and their families from their homes.' It went on: 'We are determined to save lives. Our challenge is 
above all moral and humanitarian ... We acknowledge a shared responsibility to manage large movements of refugees and migrants in a humane, sensitive, compassionate and people-centred manner.' Moreover, the resolution affirmed:

We strongly condemn acts and manifestations of racism, racial discrimination, xenophobia and related intolerance against refugees and migrants, and the stereotypes often applied to them, including on the basis of religion or belief. Diversity enriches every society and contributes to social cohesion. Demonizing refugees or migrants offends profoundly against the values of dignity and equality for every human being, to which we have committed ourselves.

The declaration also reasserted the 1951 refugee convention and its 1967 protocol:

We reaffirm that international refugee law, international human rights law and international humanitarian law provide the legal framework to strengthen the protection of refugees. We will ensure, in this context, protection for all who need it ... We reaffirm respect for the institution of asylum and the right to seek asylum. We reaffirm also respect for and adherence to the fundamental principle of non-refoulement in accordance with international refugee law.' ${ }^{67}$

Building on this, in December 2016, UNHCR (2016: 10) elaborated what a 'revitalized asylum system in the EU' would look like. It would provide access to territory, register and receive new arrivals properly, allocate responsibility for asylum-seekers among member states and ensure that they were adequately equipped. It would guarantee the right to asylum, enhance security screening and facilitate the management of population movements. It would include the following elements:

- a common registration system,

- prioritization of family reunion,

- accelerated and simplified procedures for asylum determination,

- a distribution mechanism for EU member states under pressure,

- a common approach to unaccompanied and separated children,

- incentives for compliance with the new system, and

- an efficient system for return.

UNHCR (ibid.: 19) stressed the importance of integration, which it described as a 'two-way process' between refugees and their host communities. Chapters 6 and 7 will elaborate how, on the foundation of these universal norms, and with integration conceived precisely in this 'two-way' manner, the interculturalist paradigm for the management of Europe's growing diversity has been articulated and elaborated. 


\section{SECURING THE STATE}

The measures of 'externalization' of the refugee Other have been matched within Europe by reinforcements of the state apparatus. This 'securitization' process has been represented as supporting the 'lawabiding' citizen, but its fortification of the ramparts of the stateincluding through increasingly expensive investment in technologies and tools of security and surveillance, amid fiscal austerity, in liaison with their corporate suppliers (Jones, 2017) - is the antithesis of the citizencentred approach to which a human-security perspective would lead (Kaldor, 2007). Research across EU member states by Amnesty International (2017c: 6) concluded:

The last two years ... have witnessed a profound shift in paradigm across Europe: a move from the view that it is the role of governments to provide security so that people can enjoy their rights, to the view that governments must restrict people's rights in order to provide security. The result has been an insidious redrawing of the boundaries between the powers of the state and the rights of individuals.

Individual EU states and regional bodies have responded to the attacks by proposing, adopting and implementing wave after wave of counter-terrorism measures that have eroded the rule of law, enhanced executive powers, peeled away judicial controls, restricted freedom of expression and exposed everyone to government surveillance. Brick by brick, the edifice of rights protection that was so carefully constructed after the Second World War is being dismantled.

Amnesty International expressed particular concern about the tendency for states of emergency, concentrating power in the hands of the executive with little or no judicial scrutiny, to become embedded in ordinary law, warning that 'the disturbing idea that Europe faces a perpetual emergency is beginning to take hold' (ibid.: 12).

Immediately after the November 2015 Islamist attacks in Paris, a state of emergency was introduced in France and repeatedly renewed. Yet while it facilitated huge sweeps by the police, this was not reflected in actual arraignments of suspects for criminal offences: in February 2017 the European Network Against Racism reported that there had been 3594 raids on houses, mosques and prayer halls, as well as house arrests, across France, yet all this had led only to six criminal investigations and one trial, then in train. ${ }^{68}$ A parliamentary inquiry reporting in July 2016 concluded that the state of emergency had been less effective than existing legislation to deal with violence and should be ended (McQueen, 2017). 
The state of emergency allowed prefects across the country to ban any public gathering deemed a 'threat to public order'. According to Amnesty International, by 5 May 2017, this broad power had been used to issue 155 decrees banning public assemblies. A further 639 measures had prevented named individuals attending such assemblies, which in 574 cases involved protests against a controversial 'reform' of labour law then in train, seen by its opponents as undermining labour-market regulation. Amnesty International claimed that under the guise of fighting 'terrorism' the state was clamping down on freedom of assembly. ${ }^{69}$

The new French president, Macron, introduced legislation to end the state of emergency. But as it came to the Assemblée nationale in September 2017, Le Monde commented that it would in fact insert the main elements of the state of emergency into ordinary law. And it declared: 'L'impératif de la sécurité ne peut conduire à la remise en cause des libertés individuelles, l'ADN d'une démocratie.'70 Amid criticism from UN rapporteurs concerned with human rights, the interior minister, Gérard Collomb, unwittingly acknowledged that the premise of the move was the very ineffectuality of the measures entailed in reducing violence: it was 'a lasting response to a lasting threat', he said. ${ }^{71}$

On the wider European canvas, in early 2017, the EU adopted a new directive on 'combating terrorism'. ${ }^{72}$ This followed on from a UN Security Council resolution in September 2014 concerning 'foreign terrorist fighters'. ${ }^{73}$ With Malta holding the six-month EU presidency, its justice minister, Owen Bonnici, said that 'the message is now clear: foreign fighters, whether they travel to, from or within the EU, will be stopped'. ${ }^{74}$

The new directive had been widely condemned on publication by human rights NGOs, including Amnesty International and Human Rights Watch. They warned that the 'overly broad' language of the directive could lead to the criminalizing of public protests and other peaceful acts, to the suppression of freedom of expression protected under international law, including expression of dissenting political views, and to other unjustified limitations on human rights. The directive's 'punitive measures' also posed the risk of being disproportionately applied and implemented in a manner that discriminated against specific ethnic and religious communities, they said. ${ }^{75}$

But what then happens when the perpetrator of violence stems not from the stigmatized Other but is very much part of the 'host' community Self? Here a linguistic sleight-of-hand steps in, which the psychiatrist Kamran Ahmed has identified. ${ }^{76}$ While the 'foreign' jihadist is immediately labelled a 'terrorist' - a clear and present threat to the state and likely only part of a more fearsome international network of his 
peers-far-right perpetrators, such as Breivik, are defined as 'lone wolves': somehow they thus become 'naturally' violent individuals who are in the same moment safely distinguished from an unsullied domestic body politic.

Yet Breivik had for ten years been a member of the right-wing Norwegian Progress Party, which entered government for the first time two years after his atrocity (Bangstad, 2017). And he was highly unusual in providing an apologia for his massacre in the form of a rambling 'manifesto', which drew on a wide range of conservative thinkersincluding a long quotation from the former British Tory prime minister Winston Churchill - to endorse his claim of a fundamental incompatibility between Islam and Europe. ${ }^{77}$

In January 2017 representatives of 172 civil-society organizations from 22 countries in the Euro-Mediterranean region elaborated a 'Barcelona Declaration' at a meeting in the Catalan capital. This argued (Observatory to Prevent Extremist Violence, 2017: 7): 'In the name of the fight against terrorism, we have observed an extensive use of military power and the adoption of a repressive legal arsenal, that has not only been highly ineffective, but also responsible for dramatic human rights violations and increasing global human suffering.' The declaration contended that such a state-aggrandizing approach crowded out the very civil-society organizations that could contribute to a climate of tolerance and peace.

But, leaving aside the normative arguments raised by the NGOs, why should such an approach be 'ineffective' as they claimed? Tzvetan Todorov (2010: 7-8) points to another amplification spiral:

When 'all is permitted' in the fight against terror, a counter-terrorist starts to become indistinguishable from the initial terrorist. Furthermore, all the terrorists in the world think they are counter-terrorists, merely responding to a prior act of terror. They are not the only ones: it is always possible, and easy, to find a prior violence that supposedly justifies our present violence. But, on this way of reckoning, war will never end.

Andrew Silke (2005) points to how repressive behaviour by the British army in Northern Ireland, notably the internment without trial of hundreds of civilians from August 1971 onwards and the murder of 13 people in Derry on Bloody Sunday in January 1972, merely served to escalate the challenge from a previously moribund Irish Republican Army. And Silke turns to the story of Hercules' labours in Greek mythology to illustrate the paradox of security and the alternative approach of addressing the root causes of violence. Hercules tried to slay the monster Hydra in its lair using his great strength and power, but each time he cut off one of its heads two more grew in its place. His nephew 
Iolaus however came to the rescue, with a burning torch which cauterized the monster's wounds as each head was removed, until eventually Hydra's remains could be safely buried under a rock. All this took place under the guidance of Athena, goddess of prudent war, who, unlike the god Ares, did not glory in destruction and chaos.

\section{SURVEYING THE PUBLIC}

Securing the state has entailed an ever-enhancing apparatus of state surveillance, in search of the Other within-even at the expense of the privacy of the individual citizen, who should in terms of international human-rights standards be protected from unnecessary and/or arbitrary surveillance by the requirements that the latter should be proportionate and judicially specified.

In March 2017 the UN special rapporteur on the right to privacy, Joseph Cannataci, presenting his report to the Human Rights Council, said: 'There is little or no evidence to persuade me of either the efficacy or the proportionality of some of the extremely intrusive measures that have been introduced by new surveillance laws in France, Germany, the UK and the USA.' Such measures amounted, in part, to 'gesture politics' by politicians who wished to be seen to be doing something, he said, even if the laws did not work in practice. Cannataci urged policy-makers: 'Desist from playing the fear card, and improve security through proportionate and effective measures, not with unduly disproportionate privacyintrusive laws.' 78

The growth of Orwell's Big Brother surveillance state has indeed been remarkably unsuccessful-even in its own terms. Not only have attacks continued across the continent but a feature of their ex-post-facto analysis in a number of cases has been the revelation that the perpetrator(s) had previously come to the attention of the authorities but had somehow slipped through. This has been so recurrent as to be inexplicable in terms of individual acts of negligence or the impossibility of keeping every potential suspect under 24-hour surveillance with finite resources.

For example, the perpetrators of the attacks at a concert in Manchester in May 2017, which killed 22 people, and at Westminster Bridge in London in March of the same year, which left five dead, were each known to the British security service, MI5. And in the wake of another attack on London Bridge in June, killing seven, two individuals, one a former friend, came forward to say that they had previously reported one of the alleged perpetrators to the police because of his fundamentalist attitudes; indeed he was even apparently caught on camera in a television 
documentary about jihadism in Britain shown in 2016, involved in an altercation with the police. ${ }^{79}$ The assailant who said he wanted to 'die for Allah' and was shot dead at Orly airport by soldiers in March 2017 had been identified by the French authorities as an Islamist when he served a sentence for drug trafficking several years earlier. ${ }^{80}$

A specific manifestation of the paradox of security identified above appears to be the explanation. On the one hand, the technological capacity offered by modern global communications networks, allied to pusillanimous democratic and judicial regulation of policing and intelligence agencies-insulated thereby from proper scrutiny of their performance-makes unprecedented mass surveillance possible, including on a transnational scale, as the former National Security Agency whistleblower Edward Snowden revealed in 2013. On the other hand, the stereotyped construction of 'Muslims' as a homogeneous suspect group-regardless of whether individuals prioritize religion in their identity, or even believe at all, never mind whether they translate any such belief into an Islamist political subjectivity-means a huge swath of the population is rendered a legitimate object of such surveillance.

Targeted intelligence-gathering on specific individuals who really should be the focus of policing attention is thus swamped by mass surveillance of any and all who could potentially be caught up in the dragnet, at the expense of their rights to privacy and free expression under the European Convention on Human Rights, according to the rapporteur on mass surveillance for the Parliamentary Assembly of the Council of Europe (PACE), the Dutch Christian-democrat member of parliament Pieter Omtzigt. Noting that the perpetrators of the attack on the Boston marathon in April 2013 and on the offices of Charlie Hebdo in Paris in January 2015 had been on the radar of the authorities for some time, he wrote with a colleague (Omtzigt and Schirmer, 2015): 'In short, mass surveillance may actually help terrorists because it diverts limited resources away from traditional law enforcement, which gathers more intelligence on a smaller set of targets.'

According to Čas et al (2017: 7), mass-surveillance systems inevitably generate high numbers of suspects if they are set sensitively enough to detect potential threats dependably; but these (false and correct) positive results are too manifold to be handled by law-enforcement agencies in a meaningful way. And they warn:

The inherent promise of the privacy-security trading-off metaphor that surveillance is automatically increasing security does not only cause misallocations of resources between security measures in a short-term perspective, it also causes long-term misallocations by prioritizing end-of-pipe solutions in 
comparison to targeting root causes of insecurity. In a more general way, this technological bias further reinforces already strong tendencies to focus on specific aspects of security. Security threats for which remedies involving surveillance technologies are promoted gain in attention at the expense of social and societal security issues, which would require policy measures to maintain economic or social wellbeing.

The film-maker Deeyah Khan researched the motivations of individuals in Britain who came to espouse a jihadist perspective for her 2015 documentary, Jihad: A Story of the Others. ${ }^{81}$ Her interviews, probing behind the 'caricature', revealed individuals socialized into a world where they had found themselves at the bottom of the ethnic social hierarchy, subjected to routine racism, while chafing at sexually oppressive south-Asian family structures. Struggling to remove the taint of stigma from emotionally impoverished lives, they found an imaginary resolution through embracing Islamism, feeling themselves thereby elevated as participants in a 'noble' global cause. As to the answers, Khan concluded from her investigation: 'We need to look beyond what divides us and come together to create a society where we all belong.'

Khan's arguments were independently endorsed by the head of the 'Prevent' programme in Britain, Simon Cole, chief constable of Leicestershire. A study of 500 individuals referred to an 'anti-radicalization' scheme had found in 44 per cent of cases, and possibly in another 15 per cent, a link to a mental-health vulnerability. ${ }^{82}$ Cole noted that other factors favouring 'radicalization' could be anger at western foreign policy, alienation, socio-economic deprivation and religious ideologyjihadism offered 'some sort of glamour, some sort of position in society' to those experiencing 'lack of opportunity, feeling outside of society, not feeling engaged or within society, and finding a way to rail against it'.

\section{THE REAL CHALLENGE}

This weary pessimism and inchoate thrashing around reflects a fundamental misrecognition of the real challenge confronting Europe. That challenge is to manage, within Europe and vis-à-vis the newcomers it attracts, the relationship between Europe's perceived (white, Christian) indigenous Self and the stigmatized Others (refugees and 'Muslims') who have come to comprise its 'folk devils', in the discourse of moral panics (Bauman, 2007: 43). Indeed, unless one were to assume that it would be either feasible or desirable to make a Canute-like attempt to stop the movement of people to its shores in a globalized world, then, as Bauböck and Tripkovic (2017: 1-2) affirm, 'The prospect of a persisting 
flow of refugees and migrants in the coming years makes integration a crucial issue for the future of Europe.'

The challenge, thus reframed, is by no means intractable-merely very difficult and never-concluding. Indeed it is a challenge to embrace as a goal, because there is much evidence from a range of disciplines (including social psychology and economics) that well-managed, diverse and open societies perform better than those which are closed and monocultural, particularly in a 'networked' age.

And we are now much clearer than even a decade ago as to the means to pursue that goal, through the elaboration of the new paradigm of intercultural integration and its successful experimentation on the ground, notably through the standard-setting work not of the EU-where crisis talk has prevailed-but of the Council of Europe. As Ricard ZapataBarrero (2017) has observed, 'In such times of turmoil and in this context of a crisis of ideas, interculturalism may help light the way, enjoying as it does some traction in policy and political spheres, and some support from experts and in academic circles, indispensable conditions for being considered a policy paradigm.'

\section{THE STRUCTURE OF THE BOOK}

Having set the current scene with this introduction, Chapter 2 paints the backdrop, so to speak, by defining the two preceding models for the management of cultural diversity in Europe: assimilationism and multiculturalism. In essence, the former treated as unproblematic a set of national 'values', to which it was presumed all individual members of society could and should subscribe, regardless of cultural background. The latter, by contrast, conceived of each national society as composed of diverse 'communities' and contended that only equal recognition of the purported associated plural 'cultures' could bring conviviality. Chapter 3 documents the troubling events across the continent and beyond in the new millennium which threw both these models into crisis. A series of violent interethnic and anti-state eruptions indicated genuine problems of alienation which neither model was able to explain, still less assuage. Chapter 4 then dissects the flaws thereby exposed in how these prior paradigms conceptualized the relationship between Self and Other and explains thereby why the outbursts of rage took the nationally specific forms they did.

Chapter 5 introduces the exacerbating effects of a (very real) third crisis - the global crisis of a vertiginously financialized capitalism signalled by the collapse of Lehman Brothers in 2008, fostering a milieu of 
rising insecurity favourable to the scapegoating of visible others by emboldened far-right populists. Chapter 6 introduces the Council of Europe as the Europe-wide organization to which it fell to address this challenge of integration under pressure. It explains how its normative foundation in the aftermath of the second world war, as the body charged with saying 'never again' to aggressive nationalism, racism and xenophobia, left it well placed to respond-in a manner which the institutional memory of the EU, fundamentally focused on market'liberalizing' interventions, simply did not contain the capacity to do. Chapter 7 documents the emergence from within the Council of Europe of the new paradigm of intercultural integration, first codified in the 2008 White Paper on Intercultural Dialogue. It demonstrates how, while incorporating the best elements of the preceding models of assimilationism and multiculturalism, this was constructed on the secure foundations of the Council of Europe's commitment to universal norms. This provides a common 'language' for the Self and Other and promotes dialogue between them on how they can live together as equals in dignity.

Chapter 8 makes a theoretical digression to place this institutional oeuvre in a wider intellectual context. In particular, it highlights the theoretical alignment of the interculturalist paradigm with recent work across the social sciences elaborating the concept of 'cosmopolitanism'. Clearly distinguishing this concept from the popular notion of 'rootlessness', it shows how the idea of cosmopolitanism allows of the reconceptualization of the relationship between Self and Other in a new way, at all levels from the local to the global. Chapter 9 then focuses, indeed, on the local-yet transnationally-by exploring how the Council of Europe Intercultural Cities (ICCs) programme, now embracing more than 120 cities across Europe and beyond, has experimented with the new paradigm through its embrace by member municipalities. The ICCs network, as will be seen, has become a repository of good practice as to how local authorities can intervene in an interculturalist fashion to capture the potential 'diversity advantage', rather than see demographic diversification as a threat. It has convincingly demonstrated that interculturalism works.

Chapter 10 turns once again to the wider canvas and contends that Europe must embrace an ethos of 'hospitality' if it is to address the challenges discussed in the introduction with other than 'crisis' talk and hand-wringing despair. It argues that this is not only in line with the moral obligations the continent faces to comply with the refugee convention but also has a material dimension. It identifies an oddly underrecognized association between relative degrees of openness to diverse 
newcomer populations and the respective dynamism of twentieth-century America, the anxiety of a post-war Europe seeking to 'catch up', and the stagnation of Japan in recent decades. Finally, Chapter 11 concludes by addressing the contemporary angst in Europe, notably surrounding the EU and rendered neuralgic by 'Brexit', about the state of European construction. It boldly argues that only a return to the federalist vision of some at the heart of reconstruction as the second world war concluded can give Europe the architecture it needs to put relationships between Self and Other on a new, and firmer, footing.

\section{NOTES}

1. Human Rights Watch, 'Rohingya crisis', 28 September 2017, accessed 28 September 2017 at https://www.hrw.org/blog-feed/rohingya-crisis\#blog-309667.

2. UNHCR Population Statistics, accessed 30 October 2017 at http://popstats.unher.org/en/ overview.

3. 'Saad al-Hariri: Lebanon has become a big refugee camp', Al Jazeera, 1 April 2017, accessed 21 July 2017 at http://www.aljazeera.com/news/2017/04/saad-al-hariri-lebanonbig-refugee-camp-170401045951087.html.

4. 'Much of what we think we know is wrong', Der Spiegel, 21 March 2017, accessed 21 July 2017 at http://www.spiegel.de/international/world/eight-myths-about-migrationand-refugees-explained-a-1138053.html.

5. European Commission communication, 'Towards a reform of the Common European Asylum System and enhancing legal avenues to Europe', 6 April 2016, accessed 4 October 2017 at https://ec.europa.eu/home-affairs/sites/homeaffairs/files/what-we-do/policies/ european-agenda-migration/proposal-implementation-package/docs/20160406/towards_a_ reform_of_the_common_european_asylum_system_and_enhancing_legal_avenues_to_ europe_-_20160406_en.pdf.

6. 'EU opens sanctions procedure against Hungary, Poland and Czech Republic over refugees', Euractiv, 13 June 2017, accessed 9 July 2017 at http://www.euractiv.com/ section/justice-home-affairs/news/eu-opens-sanctions-procedure-against-hungary-polandand-czech-republic-over-refugees/.

7. 'EU's top court dismisses Hungary and Slovakia case against refugee quotas', Euronews, 6 September 2017, accessed 6 September 2017 at http://www.euronews.com/2017/09/06/eus-top-court-dismisses-hungary-and-slovakia-case-against-taking-in-asylum.

8. 'Furious Hungary vows to fight on against EU refugee quotas', Irish Times, 6 September 2017, accessed 6 September 2017 at https://www.irishtimes.com/news/world/europe/ furious-hungary-vows-to-fight-on-against-eu-refugee-quotas-1.3211667.

9. European Commission, 'Member states' support to emergency relocation mission (as of 20 September 2017)', accessed 22 September 2017 at https://ec.europa.eu/home-affairs/sites/ homeaffairs/files/what-we-do/policies/european-agenda-migration/press-material/docs/state of_play_-_relocation_en.pdf.

10. European Commission, 'Relocation: Commission refers the Czech Republic, Hungary and Poland to the Court of Justice', 7 December 2017, accessed 7 December 2017 at http://europa.eu/rapid/press-release_IP-17-5002_en.htm.

11. This is graphically represented in the world map of conflict produced annually as part of the Heidelberg Conflict Barometer, accessed 20 July 2017 at https://www.hiik.de/de/ karten/2016/Global_National_all_conflicts_300dpi.pdf. 
12. '46 years of terrorist attacks in Europe, visualized', Washington Post, 17 July 2017, accessed 5 August 2017 at https://www.washingtonpost.com/graphics/world/a-history-ofterrorism-in-europe/?tid=ss_fb.

13. 'How terrorism in the West compares to terrorism everywhere else', Washington Post, 16 July 2016, accessed 5 August 2017 at https://www.washingtonpost.com/graphics/world/ the-scale-of-terrorist-attacks-around-the-world/.

14. 'Norway's prime minister Jens Stoltenberg: we are crying with you after terror attacks', Huffington Post, 24 July 2011, accessed 2 August 2017 at http://www.huffingtonpost.co.uk/ 2011/07/24/norways-prime-minister-je_n_907937.html.

15. 'Tens of thousands sing in protest at Breivik trial', Reuters, 26 April 2012, accessed 2 August 2017 at http://www.reuters.com/article/us-norway-breivik-protest-idUSBRE83 P0IB20120426.

16. "UN human rights chief attacks Europe's "chilling indifference" to refugees as 2017 sees record deaths', Independent, 8 March 2017, accessed 24 July 2017 at http://www. independent.co.uk/news/world/europe/refugee-crisis-migrants-asylum-seekers-latest-un-zeidhussein-human-rights-chilling-indifference-a7619301.html.

17. 'Polish PM draws link between London attack and EU migrant policy', Reuters, 23 March 2017, accessed 21 July 2017 at http://uk.reuters.com/article/uk-europe-migrants-polandidUKKBN16U0TC.

18. European Commission communication COM(2015) 185 final, 28 April 2015, accessed 29 August 2017 at https://ec.europa.eu/home-affairs/sites/homeaffairs/files/e-library/ documents/basic-documents/docs/eu_agenda_on_security_en.pdf.

19. European Commission communication COM(2015) 240 final, 13 May 2015, accessed 29 August 2017 at https://ec.europa.eu/home-affairs/sites/homeaffairs/files/what-we-do/ policies/european-agenda-migration/background-information/docs/communication_on_the_ european_agenda_on_migration_en.pdf.

20. European Commission communication COM(2016) 602 final, 14 September 2016, accessed 29 August 2017 at https://ec.europa.eu/home-affairs/sites/homeaffairs/files/whatwe-do/policies/european-agenda-security/legislative-documents/docs/20160914/enhancing_ security_in_a_world_of_mobility_en.pdf.

21. 'Donald Trump gets tough on refugees', The Economist, 28 January 2017, accessed 8 July 2017 at https://www.economist.com/blogs/democracyinamerica/2017/01/keep-yourhuddled-masses-0.

22. 'Hungary completes new anti-migrant border fence with Serbia', Euronews, 28 April 2017, accessed 18 July 2017 at http://www.euronews.com/2017/04/28/hungary-completes-newanti-migrant-border-fence-with-serbia.

23. Council of Europe, 'Hungary: court awards $€ 20,000$ to asylum seekers after human rights law breaches', 15 March 2017, accessed 21 July 2017 at http://www.humanrightseurope. org/2017/03/hungary-court-awards-e20000-to-asylum-seekers-after-human-rights-lawbreaches/.

24. UNHCR, 'UNHCR chief visits Hungary, calls for greater access to asylum, end to detention and more solidarity with refugees', 12 September 2017, accessed 13 November 2017 at http://www.unhcr.org/news/press/2017/9/59b809d24/unhcr-chief-visits-hungarycalls-greater-access-asylum-end-detention-solidarity.html.

25. 'Thousands of refugee children sleeping rough in sub-zero Serbia, says UN', The Guardian, 24 January 2017, accessed 10 August 2017 at https://www.theguardian.com/ weather/2017/jan/24/thousands-refugee-children-sleep-rough-sub-zero-serbia-un.

26. 'Migrants stranded in Serbian no-man's land', Deutsche Welle, 28 July 2016, accessed 10 August 2017 at http://www.dw.com/en/migrants-stranded-in-serbian-no-mans-land/a19429213.

27. Human Rights Watch, 'Poland ignores European court over return of asylum seeker', 15 June 2017, accessed 12 July 2017 at https:/www.hrw.org/news/2017/06/15/polandignores-european-court-over-return-asylum-seeker. 
28. European commissioner for human rights, Annual Activity Report 2016, 6 April 2017, accessed 30 December 2017 at https://wcd.coe.int/com.instranet.InstraServlet?command $=$ com.instranet.CmdBlobGet $\&$ InstranetImage $=2967760 \&$ SecMode $=1 \&$ DocId $=2400520 \&$ Usage $=2$.

29. Eurobarometer 82, autumn 2014, accessed 20 September 2017 at http://ec.europa.eu/ commfrontoffice/publicopinion/archives/eb/eb82/eb82_first_en.pdf.

30. 'Nigel Farage's anti-migrant poster reported to police', The Guardian, 16 June 2016, accessed 20 September 2017 at https://www.theguardian.com/politics/2016/jun/16/nigelfarage-defends-ukip-breaking-point-poster-queue-of-migrants.

31. Eurobarometer 87, spring 2017, relevant spreadsheet accessed 20 September 2017 at http://data.europa.eu/euodp/en/data/dataset/S2142_87_3_STD87_ENG.

32. Author's calculations. Data available at http://nesstar.ess.nsd.uib.no/webview/ (accessed 6 December 2017). Note that a population weighting has been applied to offset the effect of similar sample sizes but contrasting population sizes across the survey countries.

33. 'Macron lays out vision for profound changes in post-Brexit EU', The Guardian, 26 September 2017, accessed 27 September 2017 at https://www.theguardian.com/world/ 2017/sep/26/profound-transformation-macron-lays-out-vision-for-post-brexit-eu; 'Les principales propositions d'Emmanuel Macron pour relancer le projet européen', Le Monde, 26 September 2017, accessed 27 September 2017 at http://www.lemonde.fr/europe/ article/2017/09/26/les-principales-propositions-d-emmanuel-macron-pour-relancer-le-projeteuropeen_5191799_3214.html.

34. 'Torture returns to Turkey', The Economist, 7 September 2017, accessed 8 September 2017 at https://www.economist.com/news/europe/21728648-crackdown-gets-brutal-torturereturns-turkey.

35. Human Rights Watch, 'EU/Greece: asylum seekers' silent mental health crisis', 12 July 2017, accessed 12 July 2017 at https://www.hrw.org/news/2017/07/12/eu/greece-asylumseekers-silent-mental-health-crisis.

36. 'Migrant mental health crumbles in Greece: rights groups', Reuters, 15 March 2017, accessed 21 July 2017 at http://www.reuters.com/article/us-europe-migrants-greeceidUSKBN16M35N.

37. "Horrific" levels of child abuse in unsafe refugee camps, warns EU', The Guardian, 24 April 2017, accessed 18 July 2017 at https://www.theguardian.com/global-development/ 2017/apr/24/eu-urgent-protection-23000-unaccompanied-child-refugees-squalid-campsgreece-italy.

38. UNHCR, 'UNHCR urges action to ease conditions on Greek islands', 8 September 2017, accessed 9 September 2017 at http://www.unhcr.org/news/briefing/2017/9/59b24a377/ unhcr-urges-action-ease-conditions-greek-islands.html.

39. 'The refugee scandal on the island of Lesbos', Der Spiegel, 24 November 2017, accessed 24 November 2017 at http://www.spiegel.de/international/europe/conditions-on-lesbosworsen-for-refugees-and-residents-a-1180209.html\#ref=rss.

40. 'Greek refugee camps "beyond desperate" as islanders protest in Athens', The Guardian, 6 December 2017, accessed 6 December 2017 at https://www.theguardian.com/world/2017/ dec/06/aid-groups-warn-of-looming-emergency-at-greek-asylum-centres.

41. Oxfam, 'Greece intends to move 5000 people to mainland but thousands still trapped on islands', 8 December 2017, accessed 12 December 2017 at https://www.oxfam.org/en/ pressroom/reactions/greece-intends-move-5000-people-mainland-thousands-still-trappedislands.

42. 'EU rejects Italian request to open ports to migrants', Euronews, 6 July 2017, accessed 9 July 2017 at http://www.euronews.com/2017/07/06/eu-rejects-italian-request-to-openports-to-migrants.

43. Human Rights Watch, 'EU: shifting rescue to Libya risks lives', 19 June 2017, accessed 9 July 2017 at https://www.hrw.org/news/2017/06/19/eu-shifting-rescue-libya-risks-lives.

44. 'Letter dated 1 June 2017 from the Panel of Experts on Libya established pursuant to resolution 1973 (2011) addressed to the President of the Security Council', accessed 9 July 2017 at http://reliefweb.int/sites/reliefweb.int/files/resources/N1711623.pdf. 
45. 'Amid Libya's chaos, human traffickers have free rein', Al Jazeera, 2 March 2017, accessed 8 August 2017 at http://www.aljazeera.com/indepth/features/2017/03/libya-chaoshuman-traffickers-free-rein-170301092942861.html.

46. 'After conquering Benghazi, what will Libya's new strongman do next?', The Economist, 27 July 2017, accessed 1 August 2017 at http://www.economist.com/news/middle-eastand-africa/21725573-new-peace-deal-lends-legitimacy-libyas-most-powerful-general-afterconquering? frsc $=\mathrm{dg} \% 7 \mathrm{Ce}$.

47. United Nations Support Mission in Libya and Office of the UN High Commissioner for Human Rights, "Detained and Dehumanised": Report on Human Rights Abuses against Migrants in Libya', 13 December 2016, accessed 19 October 2017 at http://www.ohchr. org/Documents/Countries/LY/DetainedAndDehumanised_en.pdf.

48. 'UN urges Libyan government to shut "inhumane" refugee centres', The Guardian, 22 May 2017, accessed 17 July 2017 at https://www.theguardian.com/world/2017/may/22/ libyan-government-shut-inhumane-refugee-detention-centres-un.

49. Oxfam media briefing, 9 August 2017, accessed 15 August 2017 at https://www.oxfam.org/ sites/www.oxfam.org/files/file_attachments/mb-migrants-libya-europe-090817-en.pdf.

50. Office of the High Commissioner for Human Rights, 'Returned migrants are being robbed, raped and murdered in Libya', 7 September 2017, accessed 9 September 2017 at http://www.ohchr.org/EN/NewsEvents/Pages/DisplayNews.aspx ?NewsID=22039\&LangID $=\mathrm{E}$.

51. 'The Libyan migrant "prisons" of Europe's making', IRIN, 1 November 2017, accessed 1 November 2017 at https://www.irinnews.org/special-report/2017/11/01/libyan-migrantprisons-europe-s-making?utm_source =twitter\&utm_medium=irinsocial\&utm_campaign= irinupdates.

52. European Commission communication on the Common Asylum Policy and the Agenda for Protection, 2003, accessed 26 December 2017 at http://eur-lex.europa.eu/legal-content/EN/ TXT/?uri=CELEX\%3A52003DC0152.

53. 'The dam will hold. Until it doesn't', Foreign Policy, 6 October 2017, accessed 12 October 2017 at http://europeslamsitsgates.foreignpolicy.com/part-5-the-dam-will-hold-until-itdoesnt-germany-europe-merkel-EU-africa-migration.

54. IOM Missing Migrants project, accessed 20 July 2017 at https://missingmigrants.iom.int/.

55. 'Abandoned at sea', The Intercept, 1 April 2017, accessed 21 July 2017 at https://the intercept.com/2017/04/01/europe-keeps-its-rescue-ships-far-from-the-coast-of-libya-wherethousands-of-refugees-have-drowned/.

56. Frontex, 'European Border and Coast Guard Agency launches today', 6 October 2016, accessed 29 August 2017 at http://frontex.europa.eu/news/european-border-and-coastguard-agency-launches-today-CHIYAp.

57. 'New evidence undermines EU report tying refugee rescue group to smugglers', The Intercept, 2 April 2017, accessed 19 July 2017 at https://theintercept.com/2017/04/02/newevidence-undermines-eu-report-tying-refugee-rescue-group-to-smugglers/.

58. 'Italian prosecutors widen investigation to include MSF over migrant rescues: source', Reuters, 5 August 2017, accessed 6 August 2017 at https://www.reuters.com/article/usitaly-migrants-medecins-sans-frontier-idUSKBN1ALOHZ.

59. 'MSF suspend le sauvetage de migrants en Méditerranée', Le Monde, 13 August 2017, accessed 13 August 2017 at http://www.lemonde.fr/international/article/2017/08/13/msfsuspend-des-activites-de-sauvetage-de-migrants_5171859_3210.html.

60. Médecins Sans Frontières, 'Hindrance of humanitarian assistance will create a deadly gap in the Mediterranean sea', 12 August 2017, accessed 13 August 2017 at http://www.msf. org/en/article/hindrance-humanitarian-assistance-will-create-deadly-gap-mediterranean-sea.

61. 'NGOs pull out of Mediterranean migrant operations', Euronews, 15 August 2017, accessed 15 August 2017 at http://www.euronews.com/2017/08/15/ngos-pull-out-ofmediterranean-migrant-rescue-operations.

62. Office of the High Commissioner, 'Italy-EU search and rescue code could increase Mediterranean deaths, UN expert warns', 15 August 2017, accessed 10 October 2017 at 
http://www.ohchr.org/EN/NewsEvents/Pages/DisplayNews.aspx?NewsID=21971\&LangID $=\mathrm{E}$.

63. 'Hardening European policies keep refugee children apart from their families', IRIN, 20 April 2017, accessed 21 July 2017 at http://www.irinnews.org/feature/2017/04/20/ hardening-european-policies-keep-refugee-children-apart-their-families.

64. 'Ministers urged to end "cruel" policy on child refugees' relatives', The Guardian, 30 March 2017, accessed 21 July 2017 at https://www.theguardian.com/uk-news/2017/mar/30/ ministers-urged-to-end-cruel-policy-on-child-refugees-family-members.

65. Médecins Sans Frontières, 'One year after the EU-Turkey deal: migrants and asylumseekers are paying the price with their health', 14 March 2017, accessed 22 July 2017 at http://www.msf.org/en/article/one-year-after-eu-turkey-deal-migrants-and-asylum-seekersare-paying-price-their-health.

66. UN News Centre, "Migrant-bashing has dangerously become the norm" in Europe-UN rights expert', 18 February 2016, accessed 22 July 2017 at http://www.un.org/apps/news/ story.asp?NewsID=53264\#.WXOjQ4jyvIU.

67. UN General Assembly, '71.1. New York Declaration for Refugees and Migrants', resolution adopted by the General Assembly on 19 September 2016, accessed 8 December 2017 at http://www.unher.org/uk/57e39d987.

68. European Network Against Racism, 'EU counter-terrorism law opens door to discrimination and human rights abuses', 16 February 2017, accessed 7 August 2017 at http://enareu.org/EU-counter-terrorism-law-opens-door-to-discrimination-and-human-rights-abuses1306.

69. Amnesty International, 'France: unchecked clampdown on protests under guise of fighting terrorism', 31 May 2017, accessed 2 August 2017 at https://www.amnesty.org/en/latest/ news/2017/05/france-unchecked-clampdown-on-protests-under-guise-of-fighting-terrorism/.

70. 'The security imperative cannot lead to putting in question individual liberties, the DNA of a democracy' [my translation] 'Les risques de l'état d'urgence permanent', Le Monde, 13 September 2017, accessed 13 September 2017 at http://www.lemonde.fr/idees/article/2017/ 09/13/les-risques-de-1-etat-d-urgence-permanent_5184887_3232.html.

71. 'Macron's counter-terror bill risks France's human rights record, say UN experts', The Guardian, 28 September 2017, accessed 29 September 2017 at https://www.theguardian. com/world/2017/sep/28/macrons-counter-terror-bill-risks-frances-human-rights-record-saysun.

72. European Union directive on 'combating terrorism', 23 February 2017, accessed 7 August 2017 at http://data.consilium.europa.eu/doc/document/PE-53-2016-INIT/en/pdf.

73. Accessed 7 August 2017 at http://www.un.org/en/sc/ctc/docs/2015/SCR\%202178_2014_ EN.pdf.

74. European Council, 'EU strengthens rules to prevent new forms of terrorism', 7 March 2017, accessed 7 August 2017 at http://www.consilium.europa.eu/en/press/press-releases/ 2017/03/07-rules-to-prevent-new-forms-of-terrorism/.

75. Human Rights Watch, 'EU counterterrorism directive seriously flawed', 30 November 2016, accessed 7 August 2017 at https://www.hrw.org/news/2016/11/30/eu-counter terrorism-directive-seriously-flawed.

76. 'Terrorism or mental health problem? Let's not jump to conclusions', The Guardian, 27 June 2017, accessed 1 August 2017 at https://www.theguardian.com/commentisfree/2017/ jun/27/terror-patients-islamist-far-right-extremist-mental-health?CMP=share_btn_tw.

77. '2083: A European declaration of independence', accessed 1 August 2017 at https:// info.publicintelligence.net/AndersBehringBreivikManifesto.pdf.

78. Office of the United Nations High Commissioner for Human Rights, 'Too much surveillance: respect civil liberties and stop playing "fear card", says UN expert', 8 March 2017, accessed 7 August 2017 at http://www.ohchr.org/EN/NewsEvents/Pages/DisplayNews.aspx ?NewsID=21321\&LangID=E. 
79. 'Questions raised about police knowledge of London Bridge attackers', The Guardian, 5 June 2017, accessed 2 August 2017 at https://www.theguardian.com/uk-news/2017/jun/ 05/questions-raised-about-police-knowledge-of-london-bridge-attackers.

80. 'Man killed at Paris airport planned to "die for Allah": prosecutor', Reuters, 18 March 2017, accessed 7 August 2017 at http://www.reuters.com/article/us-france-shooting-airportidUSKBN16P07W.

81. Accessed on 23 July 2017 at https://www.youtube.com/watch?v=_usgevtEppg.

82. 'Police study links radicalisation to mental health problems', The Guardian, 20 May 2016, accessed 1 August 2017 at https://www.theguardian.com/uk-news/2016/may/20/policestudy-radicalisation-mental-health-problems. 